\title{
Tender coconut water an economical growth medium for the production of recombinant proteins in Escherichia coli
}

Narendrakumar Sekar, Soumya Kariyadan Veetil and Muniasamy Neerathilingam**

\begin{abstract}
Background: Escherichia coli is most widely used prokaryotic expression system for the production of recombinant proteins. Several strategies have been employed for expressing recombinant proteins in E.coli. This includes the development of novel host systems, expression vectors and cost effective media. In this study, we exploit tender coconut water (TCW) as a natural and cheaper growth medium for E.coli and Pichia pastoris.

Result: E.coli and P.pastoris were cultivated in TCW and the growth rate was monitored by measuring optical density at $600 \mathrm{~nm}\left(\mathrm{OD}_{600 \mathrm{~nm}}\right)$, where 1.55 for E.coli and 8.7 for P.pastoris was obtained after 12 and 60 hours, respectively. However, variation in growth rate was observed among TCW when collected from different localities (0.15-2.5 at $\left.\mathrm{OD}_{600 \mathrm{~nm}}\right)$, which is attributed to the varying chemical profile among samples. In this regard, we attempted the supplementation of TCW with different carbon and nitrogen sources to attain consistency in growth rate. Here, supplementation of TCW with $25 \mathrm{mM}$ ammonium sulphate (TCW-S) was noted efficient for the normalization of inconsistency, which further increased the biomass of E.coli by 2 to 10 folds, and 1.5 to 2 fold in P.pastoris. These results indicate that nitrogen source is the major limiting factor for growth. This was supported by total nitrogen and carbon estimation where, nitrogen varies from 20 to $60 \mathrm{mg} / 100 \mathrm{ml}$ while carbohydrates showed no considerable variation (2.32 to $3.96 \mathrm{~g} / 100 \mathrm{ml}$ ). In this study, we also employed TCW as an expression media for recombinant proteins by demonstrating successful expression of maltose binding protein (MBP), MBP-TEV protease fusion and a photo switchable fluorescent protein (mEos2) using TCW and the expression level was found to be equivalent to Luria Broth (LB).
\end{abstract}

Conclusion: This study highlights the possible application of TCW-S as a media for cultivation of a variety of microorganisms and recombinant protein expression.

Keywords: Coconut water, Growth media, E.coli, Pichia pastoris, Protein expression, Natural media

\section{Background}

An ideal growth medium for microbes requires many macro and micronutrients in appropriate proportion for optimal growth and metabolism. Carbon and nitrogen are the major sources for microbial growth, while trace elements like sulphur, phosphorus, vitamins etc., are micronutrients. Further, natural media has long served as a source for microbial propagation. Urine, meat extract, potato pieces, sprouted barley, soya flour etc., are some pioneer media employed for microbial growth

\footnotetext{
* Correspondence: munish@ncbs.res.in

Protein Technology Core, Centre for Cellular and Molecular Platforms, NCBS Campus, GKVK, Bellary Road, Bangalore 560 065, Karnataka, India
}

[1,2]. Even in the present days, yeast extract, beef extract, casein, are among the major ingredients of commercially available culture media [2]. Being readily available and serving as a rich source of essential nutrients for the growth of microbes, such natural components are widely used in chemically undefined media. However, these involve tedious procedures like extraction of nutrients, their maintenance, sterilization and supplementation to meet the requirements for microbial growth and development.

Tender coconut water (TCW), liquid endosperm present in the cavity of the coconut fruit consists of nutrients which comprises of $95.5 \%$ water, $4 \%$ sugars, $0.1 \%$ fat, $0.02 \%$ calcium, $0.01 \%$ phosphorous, $0.5 \%$ iron, 
considerable amounts of amino acids, mineral salts, vitamin B complex, vitamin $\mathrm{C}$ and cytokines etc. [3]. Because of the rich nutrient content in coconut water, it was noted for its wide applications in plant tissue culture, growing fungus and other microbes [4-6]. In few such studies, coconut water was used as complete growth media for Rhodotorula glutinins [7]. Whereas, Unagul et al., demonstrated the supplementation of coconut water to yeast extract-diluted seawater medium for the production of docosahexaenoic acid (DHA), which was $50 \%$ higher than that of non-supplemented media [8]. Similarly, coconut water was used as a raw material for supplementation of carbon and nitrogen in MRS- sucrose media for the production of exopolysaccharide (EPS) by Lactobacillus confusus to reduce the cost of fermentation medium [9]. In another study, Prabakaran et al., reported the production of $\delta$ endotoxin, an endogenous protein of Bacillus thuringiensis var. israelensis, (a biological control agent against mosquitoes) using coconut water as a growth medium [10]. Although the above studies focused on growth of microbes and endogenous protein production in coconut water, its application in recombinant protein production has not been demonstrated before.

In recent years, the therapeutic application of recombinant proteins has been increased immensely. Many industries are producing large quantities of recombinant proteins and the need for expression media devoid of any toxin has increased subsequently. TCW is plant derived and deficient in endotoxins which are present in other commercially available media. Hence, this isotonic beverage could be a safe alternative medium for therapeutic protein production. Since, TCW is naturally sterile, the preparation and sterilization is fairly convenient in comparison to conventionally used media. It is economical and abundantly available throughout the year (especially tropical and coastal areas), thereby contributing to its feasibility as a potential microbial growth medium.

\section{Methods}

\section{Strains and plasmids}

E.coli strains such as BL21 (DE3), BL21 (DE3) pLysS were used for protein expression studies whereas, E.coli C41 (DE3) and P.pastoris GS115 were used for growth studies. All the strains were procured from Invitrogen ${ }^{\text {тм }}$, USA. Three different constructs were used namely; maltose binding protein (MBP), a fusion of MBP with tobacco etch virus protease (MBP-TEV) and monomeric variant of photo switchable fluorescent Eos proteins (mEos2). pMAL-c5 $\times$ for expressing MBP, pMAL-c5 $\times$ harboring TEV for expressing MBP-TEV fusion and pRSET-A harbouring mEos 2 were used in this study. TEV was synthesized by GeneScripts, USA and mEos2 was a kind gift from Dr. Satyajit Mayor, NCBS, Bangaluru, India.

\section{Preparation of TCW media and agar plates}

Tender coconut fruits were obtained from different places in Bengaluru, India. Part of mesocarp and endocarp were removed to expose the surface of endosperm. Then, coconut water (TCW) was extracted and centrifuged at $4000 \mathrm{rpm}$ for 20 minutes to separate particulate matter, followed by filter sterilization with 0.22 $\mu \mathrm{m}$ filter (Millex ${ }^{\bullet}$ filter units -Millipore). TCW agar plates (Figure $1 C$ ) were prepared by mixing $25 \mathrm{ml}$ of filter sterilized TCW with $25 \mathrm{ml}$ of $4 \%$ agar (autoclaved) and microwaved for 30-60 seconds.

\section{Supplementation of TCW (TCW-S) with carbon, nitrogen and other salts}

Stock solutions of $1 \mathrm{M}\left(\mathrm{NH}_{4}\right)_{2} \mathrm{SO}_{4}, 1 \mathrm{M} \mathrm{Na} \mathrm{SO}_{4}, 1 \mathrm{M}$ $\mathrm{KH}_{2} \mathrm{PO}_{4}, 1 \mathrm{M} \mathrm{MgSO} 4$ and $80 \%$ glycerol, $20 \%$ glucose, $20 \%$ lactose and $1 \%$ amino acids cocktail (1\% of each of 17 amino acids excluding cysteine, methionine and tyrosine) were sterilized by autoclaving except glucose, $\mathrm{MgSO}_{4}$ and amino acids which were filter sterilized by $0.22 \mu \mathrm{m}$ filter. These compounds were supplemented to TCW at a final concentration of; $25 \mathrm{mM}\left(\mathrm{NH}_{4}\right)_{2} \mathrm{SO}_{4}$, $5 \mathrm{mM} \mathrm{Na}_{2} \mathrm{SO}_{4}, 50 \mathrm{mM} \mathrm{KH_{2 }} \mathrm{PO}_{4}, 2 \mathrm{mM} \mathrm{MgSO}, 0.8 \%$ glycerol, $0.2 \%$ glucose , $0.5 \%$ lactose and $0.36 \%$ amino acid cocktail (Table 1).

\section{Estimation of total carbohydrate, nitrogen and other metabolites in TCW}

The concentration of amino acids and metabolites were estimated using LC-MS/SRM (Liquid Chromatography-Mass Spectrometry/Selected Reaction Monitoring) method. All amino acids, acetone, formic acid were obtained from Sigma-Aldrich (Bangalore, India). The corresponding deuterated internal standards (ISTD) were obtained from CDN isotopes (Quebec, Canada). Acetonitrile and water used for the chromatography were obtained from Thermo Fisher Scientific. $10 \mathrm{ng}$ of ISTD mix of all amino acids were spiked with $10 \mu \mathrm{L}$ of TCW and amino acids were extracted by precipitating the proteins using $200 \mu \mathrm{L}$ of acetone (0.1\% FA). It was then vortexed, centrifuged (13000 rpm, 5min) and the supernatant was dried using speed vacuum. The derivatization of amino acids was done in the similar way using the 6-aminoquinolyl-N-hydroxysuccinimidyl carbamate as previously published procedure [11]. The analysis was done using the LC-MS system (LC-Agilent 1290 infinity series, MS- Thermo Fisher TSQ vantage). The single major product ion of $\mathrm{m} / \mathrm{z} 171$ was used for the SRM transitions. LC conditions [Solvent system A-water (0.1\% FA), B-acetonitrile (0.1\% FA), flow-200 $\mu \mathrm{L} / \mathrm{min}$, column- C-18 (2.1 × $100 \mathrm{~mm}, 1.8 \mu \mathrm{m}$, Phenomenex), gradient- 0 to $3 \mathrm{~min}-2 \% \mathrm{~B}, 3-20 \mathrm{~min}-20 \% \mathrm{~B}, 20$ to 25 min- 35\%, 25 to $27-80 \%$ B, 27-30 min-2\% B]. MS conditions [spray voltage-3700 V, ion transfer capillary 

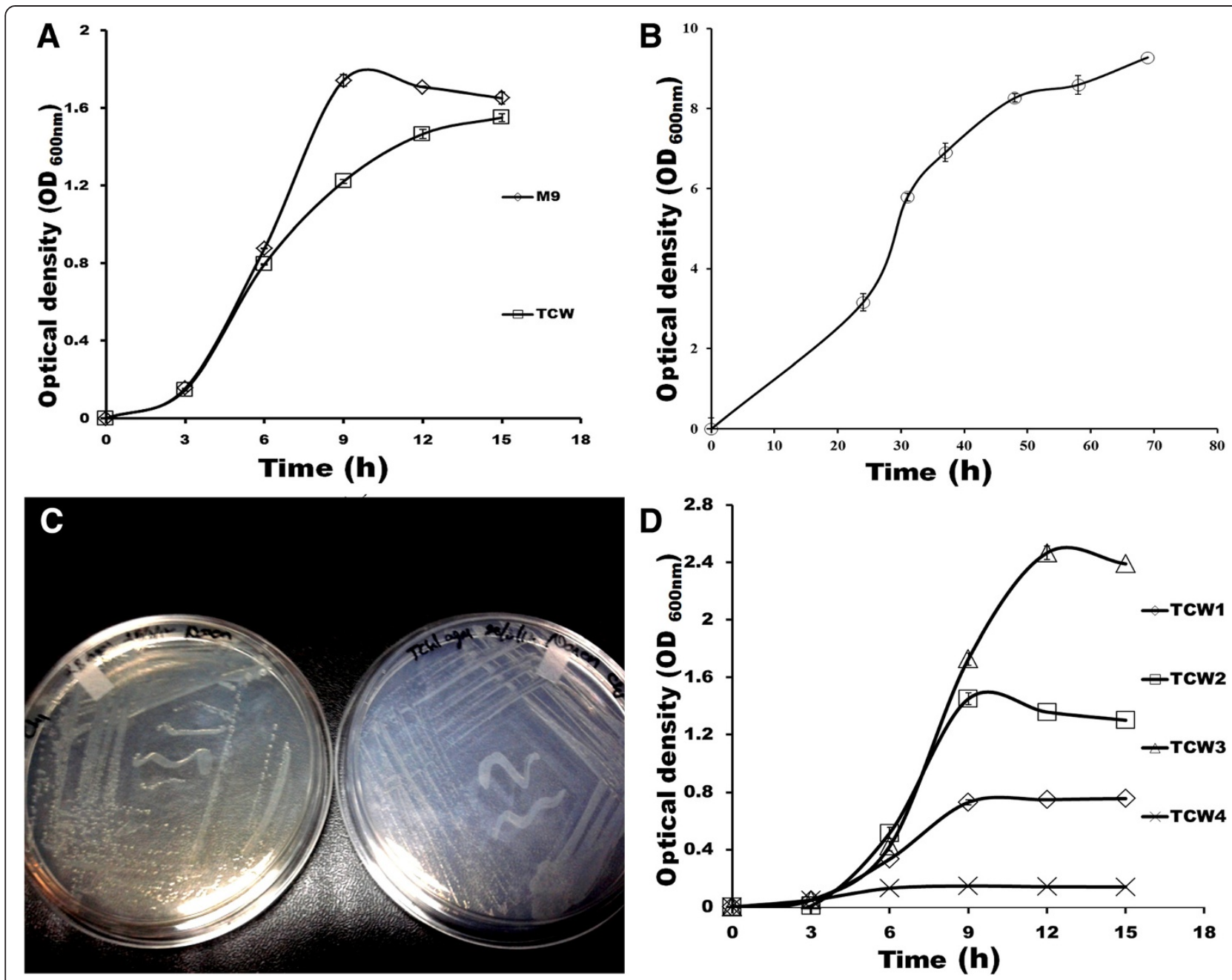

Figure 1 Growth curve of E.coli and P.pastoris in TCW. Growth curve of (A) E.coli C41 in TCW and M9 media (B) P.pastoris in TCW (C) Growth of E.coli C41 on LB agar plate (left) and TCW agar plate (right). (D) Growth curve of C41 in different TCW collected from different places. The experiments were performed in triplicates and SD has been incorporated.

temperature $270^{\circ} \mathrm{C}$, source temperature $30^{\circ} \mathrm{C}$, sheath gas 20, auxiliary gas 10 (arbitrary units), collision gas-argon, $\mathrm{S}$-lens voltage and collision energy were optimized for individual amino acids, scan time-50 millisec, ion polarity is positive). The final relative quantification was done based on the area under the curve of individual amino acid ISTDs.

Total nitrogen in TCW was estimated by conventional Kjeldahl method [12]. Total carbohydrate was measured by phenol sulphuric acid method as described by Dubious et al., [13].

Inoculum preparation and culture conditions

For growth studies, E.coli C41 (DE3) was streaked on LB-agar plates and P.pastoris GS115 on YPD (Yeast (1\%) Peptone (2\%) Dextrose (2\%) medium) agar plate, then incubated at $37^{\circ} \mathrm{C}$ and $30^{\circ} \mathrm{C}$ for overnight, respectively. A loop-full of colonies were inoculated into $10 \mathrm{ml}$ of
Table 1 List of tested supplements: $1 \mathrm{M}$ stock solutions were prepared by dissolving the salts in water

\begin{tabular}{|c|c|c|}
\hline Chemical name & $\begin{array}{l}\text { Stock solution } \\
\text { concentration }\end{array}$ & $\begin{array}{c}\text { Final } \\
\text { concentration }\end{array}$ \\
\hline$(\mathrm{NH} 4) 2 \mathrm{SO} 4$ & $1 \mathrm{M}$ & $25 \mathrm{mM}$ \\
\hline $\mathrm{Na} 2 \mathrm{SO} 4$ & $1 \mathrm{M}$ & $5 \mathrm{mM}$ \\
\hline $\mathrm{KH} 2 \mathrm{Po} 4$ & $1 \mathrm{M}$ & $50 \mathrm{mM}$ \\
\hline $\mathrm{MgSO} 4$ & $1 \mathrm{M}$ & $2 \mathrm{mM}$ \\
\hline Glycerol & $80 \%$ & $0.8 \%$ \\
\hline Glucose & $40 \%$ & $0.2 \%$ \\
\hline Lactose & $20 \%$ & $0.5 \%$ \\
\hline $\begin{array}{l}\text { Amino acid mixture }{ }^{1} \\
(- \text { cyss,-met,-tyr })^{2}\end{array}$ & $\begin{array}{l}10 \mathrm{mg} / \mathrm{ml}^{\text {each of }} \\
17 \mathrm{amino}^{2} \text { acids }^{1}\end{array}$ & $0.36 \%$ \\
\hline
\end{tabular}

The above mentioned reagents were prepared as described by Neerathilingam and Markley [21].

${ }^{1}$ Amino acid cocktail without cystein, methionine and tyrosine was prepared. 


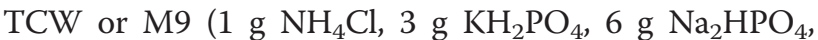
$4 \mathrm{~g}$ glucose, and $1 \mathrm{ml}$ of $1 \mathrm{M} \mathrm{MgSO}_{4} / \mathrm{L}$ ) minimal medium (wherever applicable) and incubated for overnight at $37^{\circ} \mathrm{C}$ for E.coli and $30^{\circ} \mathrm{C}$ for P.pastoris (primary culture) with $200 \mathrm{rpm}$. Primary culture (E.coli: $\sim 1.5 \times 10^{8}$, P.pastoris: $\sim 1.5 \times 10^{6}$ cells) was then inoculated into 250 $\mathrm{ml}$ flask containing $50 \mathrm{ml}$ of TCW/TCW-S/M9 (wherever applicable) and the growth was monitored by measuring $\mathrm{OD}_{600 \mathrm{~nm}}$. All the experiments were performed in triplicates and mean standard deviation was calculated.

To study protein expression in TCW, constructs of MBP and MBP-TEV fusion were transformed into BL21 (DE3) and mEos2 into BL21 (DE3) pLysS. One percent of overnight culture was inoculated into $250 \mathrm{ml}$ flask containing $50 \mathrm{ml}$ of TCW, TCW-S (supplemented) and LB media containing ampicillin $(100 \mu \mathrm{g} / \mathrm{ml})$ followed by incubation at $37^{\circ} \mathrm{C}$ with $200 \mathrm{rpm}$. The cultures were induced with IPTG (0.4 mM for MBP, MBP-TEV and 0.1 $\mathrm{mM}$ for mEos2) at $\mathrm{OD}_{600 \mathrm{~nm}}$ of $0.5-0.6$ and incubated at $30^{\circ} \mathrm{C}$ for 5 hours. Further, samples were harvested and centrifuged at 4,000 rpm for 15 minutes at $4^{\circ} \mathrm{C}$. Expression level was checked on $12 \%$ SDS-PAGE.

\section{Results and discussion}

Growth of E.coli and P.pastoris in TCW and TCW-S

TCW being rich in nutrients contains all the essential components that are required for the growth of microorganisms. In order to demonstrate its use as a complete media, E.coli was grown in TCW and a maximum $\mathrm{OD}_{600 \mathrm{~nm}}$ of 1.55 was noted after 12 hours. The growth rate was compared to that of conventional M9 media, which showed $\mathrm{OD}_{600 \mathrm{~nm}}$ maximum of 1.70 (Figure $1 \mathrm{~A}$ ) after 12 hours of incubation.

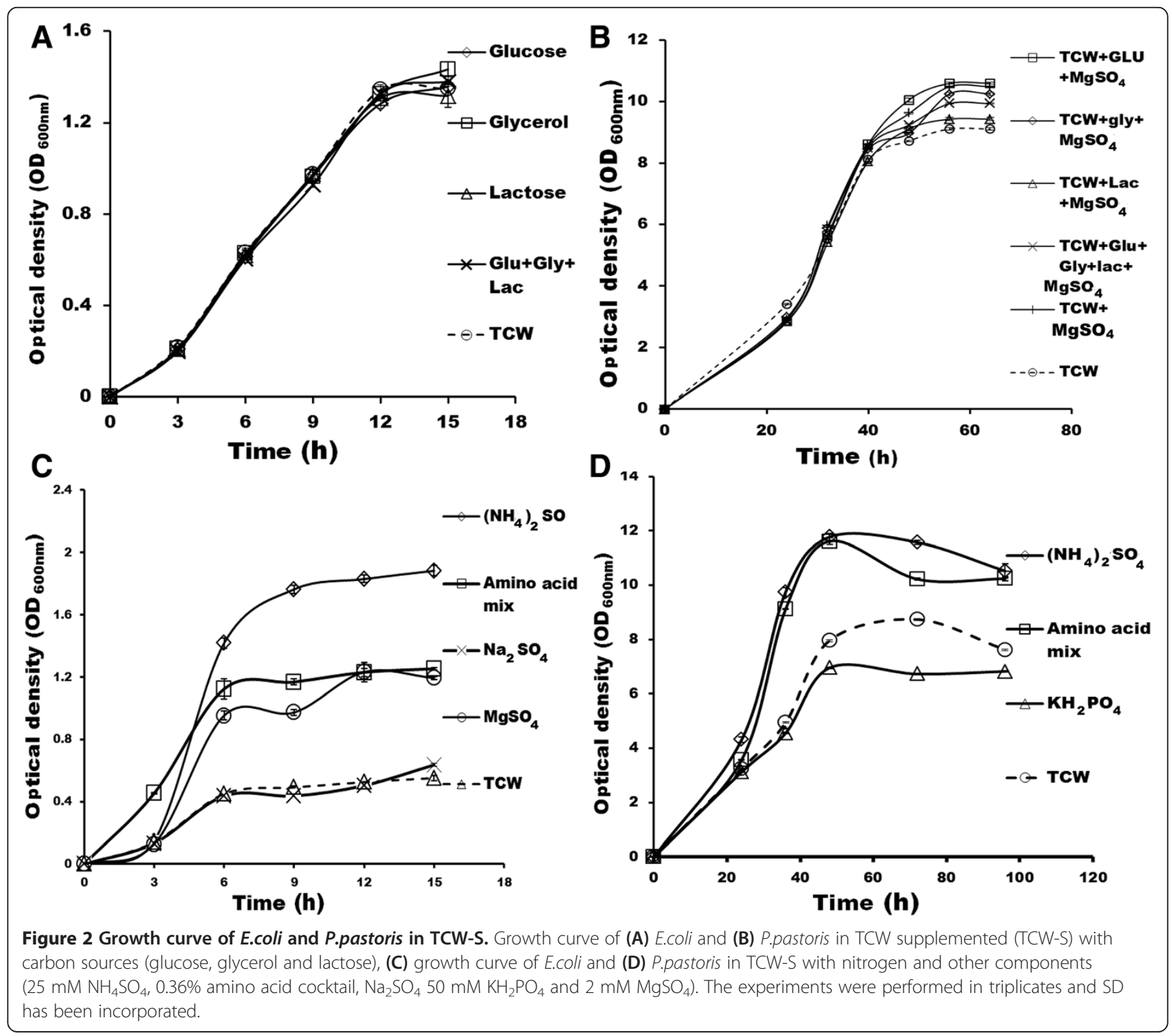


E.coli is known to grow at $\mathrm{pH} 4.0$ to 8.0 [14]. However, the optimum $\mathrm{pH}$ is reported as 6.5- 7.0 [14]. We noted the $\mathrm{pH}$ of TCW as $4.7 \pm 0.2$. In this regard, a $50 \mathrm{ml} \mathrm{sam-}$ ple was $\mathrm{pH}$ adjusted to 7.0 and growth was monitored. After overnight incubation, the $\mathrm{pH}$ was reduced and found to be equivalent to that of unadjusted TCW, with no difference in growth rate. Hence, all experiments were performed without adjusting $\mathrm{pH}$. Nevertheless, to achieve optimal condition, $\mathrm{pH}$ needs to be monitored and maintained. We also used TCW as a complete growth media for P.pastoris where a maximum $\mathrm{OD}_{600 \mathrm{~nm}}$ of 8.7 was noted after 64 hours (Figure 1B). In addition, TCW agar plates were used for plating E.coli, where the colonies appeared to be similar in morphology to that of LB agar plates (Figure $1 \mathrm{C}$ ).

Since TCW is a naturally occurring liquid, its chemical composition varies from coconut to coconut [15]. To validate and demonstrate the effect of this variation on growth, biomass of E.coli in different TCW samples were studied, which ranged from $\mathrm{OD}_{600 \mathrm{~nm}}$ of 0.15-2.5 after 12 hours of incubation (Figure 1D). This indicates that nutrients present in TCW vary with each coconut which could presumably be due to; the maturity, location and variety of coconut fruit, thus influencing its chemical profile. For instance, sugars like glucose and fructose are higher in young coconut (TCW) $[15,16]$ whereas, sucrose is the predominant sugar in mature coconut water $[17,18]$. Kuberski et al., made similar observations where, sugar content in coconut water was identified as glucose, sucrose and fructose in the proportion of approximately $50 \%, 35 \%$ and $15 \%$, respectively [19]. In another study, Vigliar et al., [3] demonstrated that the proportion of these sugars varied depending upon the stage of maturation of the coconut fruit i.e. glucose varies from $34 \%$ to $45 \%$; sucrose from $53 \%$ to $18 \%$ and fructose from $12 \%$ to $36 \%$. Similarly, other nutrient components of TCW vary significantly with degree of maturation like potassium, chloride, iron and sulphur [20].

To achieve consistency in growth rate of E.coli and P.pastoris, TCW was supplemented by adding carbon, nitrogen and other essential nutrients like magnesium, potassium and sulphur (listed in Table 1). The supplements were chosen based on the work done by Neerathilingam and Markley [21] and Studier [22]. All the compounds were supplemented either individually or in combination. The results were correlated to find the best supplement for TCW. In this regard, the addition of carbon sources such as $0.2 \%$ glucose, $0.8 \%$ glycerol and $0.5 \%$ lactose individually or in combination, did not show any significant improvement in the biomass of E.coli as compared to TCW without supplementation (Figure 2A). In case of P.pastoris, only slight improvement (1.1 to 1.17 fold) was observed after 60 hours (Figure 2B). This indicates that the limiting factor in TCW is not carbon source but other components.

Furthermore, we supplemented ammonium sulphate, amino acid cocktail, sodium sulphate and magnesium sulphate to TCW. Biomass of E.coli was improved by 4 fold in $25 \mathrm{mM}\left(\mathrm{NH}_{4}\right)_{2} \mathrm{SO}_{4}$ supplemented TCW (1.9 at $\mathrm{OD}_{600 \mathrm{~nm}}$ ), 3 fold in $0.36 \%$ amino acid supplemented TCW $\left(1.2\right.$ at $\left.\mathrm{OD}_{600 \mathrm{~nm}}\right)$ and 2.7 fold in $2 \mathrm{mM} \mathrm{MgSO}_{4}$ supplemented TCW (1.1 at $\left.\mathrm{OD}_{600 \mathrm{~nm}}\right)$ as compared to TCW without supplementations $\left(0.4\right.$ at $\left.\mathrm{OD}_{600 \mathrm{~nm}}\right)$ whereas, no considerable improvement was observed for $5 \mathrm{mM}$
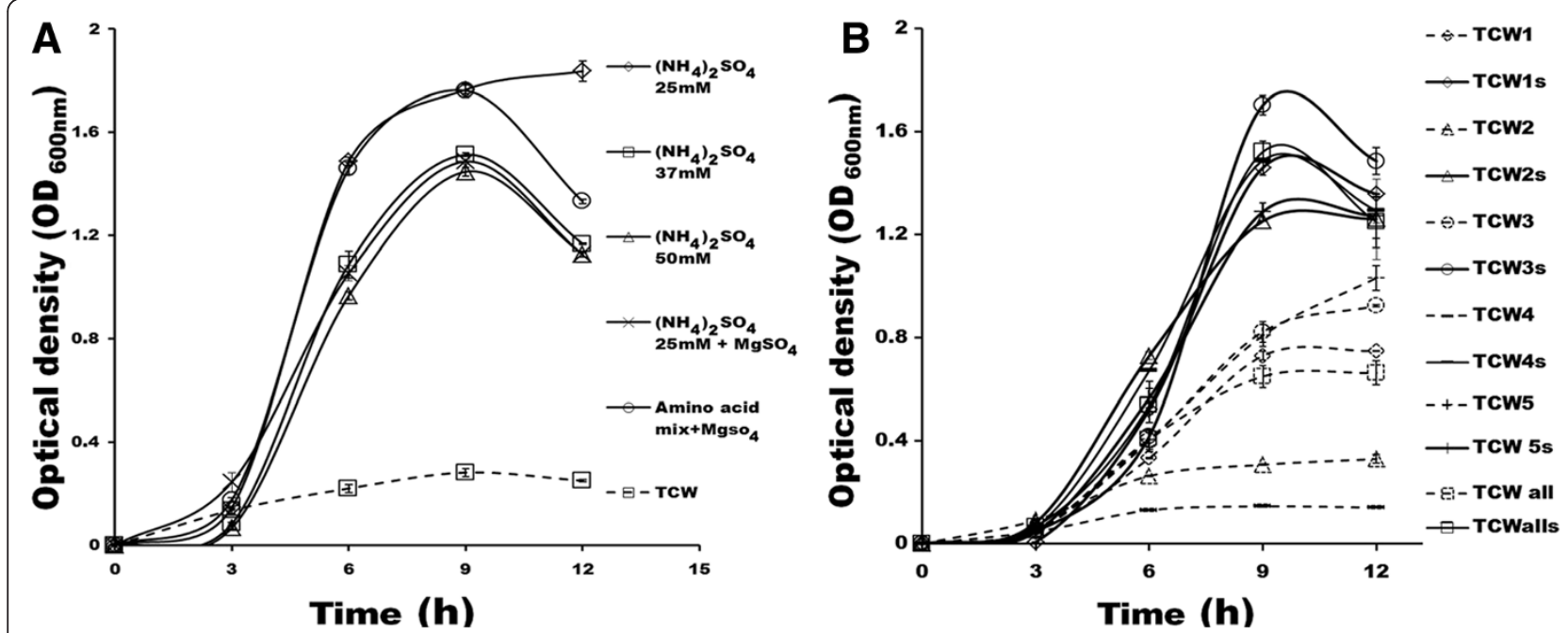

Figure 3 TCW-S optimization with nitrogen compounds. (A) Growth curve of E.coli in TCW-S supplemented with $\left(\mathrm{NH}_{4}\right)_{2} \mathrm{SO}_{4}$ at different concentration $(25,37 \& 50 \mathrm{mM})$ and $2 \mathrm{mM} \mathrm{MgSO}_{4}$ in combination with $25 \mathrm{mM}\left(\mathrm{NH}_{4}\right)_{2} \mathrm{SO}_{4}$ and $0.36 \%$ amino acid mix. $(\mathbf{B})\left(\mathrm{NH}_{4}\right)_{2} \mathrm{SO}_{4}$ supplementation in five different TCW samples (TCW-S) and comparison with its corresponding TCW. The experiments were performed in triplicates and SD has been incorporated. 
$\mathrm{Na}_{2} \mathrm{SO}_{4}$ supplementation (Figure $2 \mathrm{C}$ ). In case of P.pastoris, $\left(\mathrm{NH}_{4}\right)_{2} \mathrm{SO}_{4}$, amino acid cocktail and $\mathrm{KH}_{2} \mathrm{PO}_{4}$ were supplemented to $\mathrm{TCW}$, where biomass improved 1.5 fold in $\left(\mathrm{NH}_{4}\right)_{2} \mathrm{SO}_{4}$ supplemented TCW (11.6 at $\left.\mathrm{OD}_{600 \mathrm{~nm}}\right)$ and 1.4 fold in amino acid cocktail $\left(10.2\right.$ at $\left.\mathrm{OD}_{600 \mathrm{~nm}}\right)$, as compared to TCW without supplementation (8.7 at $\left.\mathrm{OD}_{600 \mathrm{~nm}}\right)$ while, a decreased biomass was observed

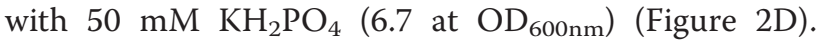
These results suggest that ammonium sulphate, amino acid and magnesium sulphate supplemented to TCW improves the biomass of both E.coli and P.pastoris considerably.
In addition, the cumulative effect of supplementation of $\left(\mathrm{NH}_{4}\right)_{2} \mathrm{SO}_{4}$ and amino acid with $\mathrm{MgSO}_{4}$ was noted separately. The biomass of E.coli was decreased in $\left(\mathrm{NH}_{4}\right)_{2} \mathrm{SO}_{4}+\mathrm{MgSO}_{4}$ whereas, amino acids $+\mathrm{MgSO}_{4}$ supplementation was equivalent to that of the $25 \mathrm{mM}$ $\left(\mathrm{NH}_{4}\right)_{2} \mathrm{SO}_{4}$. Further to check, increase in concentration of ammonium sulphate improves the biomass of E.coli, TCW was supplemented with $25 \mathrm{mM}, 37 \mathrm{mM}$ and $50 \mathrm{mM}$ of $\left(\mathrm{NH}_{4}\right)_{2} \mathrm{SO}_{4}$ and compared with TCW without supplementation. A six fold increase was observed with $25 \mathrm{mM}\left(\mathrm{NH}_{4}\right)_{2} \mathrm{SO}_{4}$ supplementation while only 4.5 fold increase was noted in $37 \mathrm{mM}$ as well as

Table 2 Chemical profile of TCW used in this study

\begin{tabular}{|c|c|c|c|c|c|c|c|}
\hline Compounds & $\begin{array}{l}\text { TCW } 1 \\
(\mu \mathrm{g} / \mathrm{ml})\end{array}$ & $\begin{array}{l}\text { TCW } 2 \\
(\mu \mathrm{g} / \mathrm{ml})\end{array}$ & $\begin{array}{l}\text { TCW } 3 \\
(\mu \mathrm{g} / \mathrm{ml})\end{array}$ & $\begin{array}{l}\text { TCW } 4 \\
(\mu \mathrm{g} / \mathrm{ml})\end{array}$ & $\begin{array}{l}\text { TCW } 5 \\
(\mu \mathrm{g} / \mathrm{ml})\end{array}$ & $\begin{array}{l}\text { TCW } 6 \\
(\mu \mathrm{g} / \mathrm{ml})\end{array}$ & $\begin{array}{l}S^{*} \\
(\mu \mathrm{g} / \mathrm{ml})\end{array}$ \\
\hline Hydroxyproline & 1.80 & 2.41 & 2.52 & 2.18 & 2.31 & 2.39 & \pm 0.23 \\
\hline Histidine & 2.03 & 2.57 & 2.94 & 1.83 & 3.61 & 3.04 & \pm 0.60 \\
\hline Asparsgine & 176.88 & 98.07 & 68.18 & 97.60 & 223.48 & 196.21 & \pm 57.92 \\
\hline Taurine & 0.07 & 0.07 & 0.14 & 0.09 & 0.09 & 0.09 & \pm 0.02 \\
\hline Serine & 8.27 & 8.03 & 8.40 & 7.01 & 11.27 & 10.36 & \pm 1.45 \\
\hline Glutamine & 6.44 & 3.32 & 2.83 & 5.81 & 5.11 & 12.49 & \pm 3.17 \\
\hline Arginine & 12.49 & 19.09 & 17.70 & 21.49 & 26.91 & 22.36 & \pm 4.43 \\
\hline Homoserine & 1.30 & 1.39 & 1.06 & 1.16 & 1.31 & 1.33 & \pm 0.11 \\
\hline Glycine & 2.90 & 2.78 & 2.80 & 2.39 & 3.00 & 3.98 & \pm 0.48 \\
\hline Aspartic acid & 0.52 & 0.25 & 0.50 & 0.31 & 0.94 & 0.71 & \pm 0.23 \\
\hline Citrulline & 1.02 & 1.37 & 1.20 & 1.10 & 1.29 & 1.23 & \pm 0.11 \\
\hline Glutamic acid & 3.43 & 1.50 & 4.93 & 1.88 & 6.22 & 5.00 & \pm 1.71 \\
\hline Threonine & 10.53 & 12.25 & 11.07 & 5.67 & 10.63 & 10.79 & \pm 2.08 \\
\hline Alanine & 193.56 & 171.85 & 252.66 & 166.57 & 248.37 & 237.76 & \pm 35.71 \\
\hline Gaba & 15.78 & 14.51 & 33.24 & 22.70 & 30.18 & 28.18 & \pm 7.07 \\
\hline Proline & 20.78 & 56.54 & 50.26 & 17.23 & 31.98 & 34.73 & \pm 14.28 \\
\hline Lysine & 0.92 & 1.27 & 1.96 & 1.50 & 2.14 & 1.71 & \pm 0.41 \\
\hline Tyrosine & 6.69 & 3.48 & 4.27 & 4.00 & 10.32 & 9.02 & \pm 2.61 \\
\hline Methonine & 0.03 & 0.04 & 0.06 & 0.16 & 0.09 & 0.11 & \pm 0.04 \\
\hline Valine & 54.69 & 52.16 & 48.32 & 52.79 & 64.44 & 62.40 & \pm 5.74 \\
\hline Isoleucine & 15.48 & 15.72 & 14.53 & 14.89 & 18.01 & 17.74 & \pm 1.34 \\
\hline Lucine & 29.35 & 24.09 & 20.21 & 25.30 & 38.48 & 34.71 & \pm 6.28 \\
\hline Phenylalanine & 7.28 & 5.03 & 5.07 & 4.80 & 8.66 & 7.81 & \pm 1.53 \\
\hline $\begin{array}{l}\text { Total amino } \\
\text { acids } \\
\text { metabolites }{ }^{1}\end{array}$ & 576.64 & 498.83 & 704.50 & 457.25 & 759.32 & 557.02 & \pm 107.19 \\
\hline $\begin{array}{l}\text { Total } \\
\text { carbohydrate }\end{array}$ & $3.9 \mathrm{~g} / 100 \mathrm{ml}$ & $3.82 \mathrm{~g} / 100 \mathrm{ml}$ & $2.82 \mathrm{~g} / 100 \mathrm{ml}$ & $2.80 \mathrm{~g} / 100 \mathrm{ml}$ & $2.32 \mathrm{~g} / 100 \mathrm{ml}$ & $2.63 \mathrm{~g} / 100 \mathrm{ml}$ & $\pm 0.611 \mathrm{~g} / 100 \mathrm{ml}$ \\
\hline Total Nitrogen ${ }^{3}$ & $33.2 \mathrm{mg} / 100 \mathrm{ml}$ & $17.542 \mathrm{mg} / 100 \mathrm{ml}$ & $33.60 \mathrm{mg} / 100 \mathrm{ml}$ & $15.0 \mathrm{mg} / 100 \mathrm{ml}$ & $57.2 \mathrm{mg} / 100 \mathrm{ml}$ & $28.630 \mathrm{mg} / 100 \mathrm{ml}$ & $\pm 13.78 \mathrm{mg} / 100 \mathrm{ml}$ \\
\hline
\end{tabular}

Amino acids and metabolites listed in the table were estimated using mass spectroscopy.

${ }^{1}$ Sum of amino acid and other metabolites concentration estimated by mass spectroscopy.

${ }^{2}$ Total carbohydrate was estimated by phenol sulphuric acid method.

${ }^{3}$ Total nitrogen was estimated by Kjeldahl method.

*SD - standard deviation. 
in $50 \mathrm{mM}\left(\mathrm{NH}_{4}\right)_{2} \mathrm{SO}_{4}$ supplemented TCW (Figure 3A). Above results suggest that the supplementation of 25 $\mathrm{mM}\left(\mathrm{NH}_{4}\right)_{2} \mathrm{SO}_{4}$ is sufficient to achieve the improved and consistent growth.

To validate the ammonium sulphate supplementation for normalizing batch to batch variation of TCW, five samples from different locations were tested. Where, 210 fold increase in biomass of E.coli in $25 \mathrm{mM}\left(\mathrm{NH}_{4}\right)$ ${ }_{2} \mathrm{SO}_{4}$ supplemented TCW was observed as compared to TCW without supplementation (Figure 3B). Also, these five samples were pooled together and $\mathrm{OD}_{600 \mathrm{~nm}} 0.6$ was noted while, upon addition of $25 \mathrm{mM}\left(\mathrm{NH}_{4}\right)_{2} \mathrm{SO}_{4}$ it increased to 1.2. This signifies that the supplementation of TCW with $25 \mathrm{mM}\left(\mathrm{NH}_{4}\right)_{2} \mathrm{SO}_{4}$ can be used for large scale applications as well, since several coconut fruits would be required to obtain sufficient volume of TCW.

\section{Carbon and nitrogen estimation of TCW and its correlation with growth}

To understand the difference in growth pattern and its correlation with nutrient contents of TCW, the chemical profile (carbohydrates, nitrogen and other metabolites) of individual TCW samples used in this study were estimated (Table 2). Phenol sulphuric acid method was adopted to estimate total carbohydrate which ranged from 2.32 to $3.96 \mathrm{~g} / 100 \mathrm{ml}$ in six different TCW samples while, total nitrogen was estimated by Kjeldahl method which fell in the range of $20-60 \mathrm{mg} / 100 \mathrm{ml}$. In addition, amino acid and other metabolites were estimated by mass spectroscopy; Asparagine, alanine, valine were present in high concentration $(>50 \mu \mathrm{g} / \mathrm{ml})$ while hydroxyl proline, histidine, taurine, glycine, homoserine, aspartic acid, citrulline, glutamic acid, lysine and methionine were noted in very low concentration $(<5 \mu \mathrm{g} / \mathrm{ml})$ in each sample. Whereas asparagine, alanine, proline, vary vastly among each sample (Standard deviation (SD) $>10$ $\mu \mathrm{g} / \mathrm{ml}$ ), while hydroxyl proline, taurine, homoserine, glycine, citrulline, lysine, methionine and aspartic acid showed considerably less variation (SD $<0.5 \mu \mathrm{g} / \mathrm{ml}$ ) (Figure 4).

As anticipated from growth patterns of E.coli and P.pastoris (discussed earlier), the above estimation shows that carbohydrate was present in high concentration with less variation among each samples whereas, total nitrogen showed greater difference (SD > $13 \mathrm{mg} / \mathrm{ml}$ ). Moreover, in Figure 3B, total nitrogen and amino acid concentration in each six different TCW samples was noted to correlate to its growth pattern. Where the sample with best $\mathrm{OD}_{600 \mathrm{~nm}}(\mathrm{TCW}-5)$ corresponded to that of highest nitrogen concentration (see Table 2) among others and likewise. Thereby, supporting the assumption discussed earlier, that nitrogen sources are the limiting factor for inconsistent growth rate observed between different TCW samples.

\section{TCW as an expression media}

Many popular bacterial expression system, contain components of the lac operon, which can be induced by IPTG. A growth media used for expression of recombinant proteins should not interfere with IPTG induction of the target protein. For example, presence of lactose or high concentration of glucose in the media interferes with the regulation of lac operator, which could result in leaky expression or no expression of the target protein $[23,24]$. Robert and Barbara, demonstrated that addition of $1 \%$ glucose to the medium will prevent leaky expression in lac based vector systems [24]. Since, TCW is devoid of lactose and also contains $\sim 1 \%$ glucose [3], it

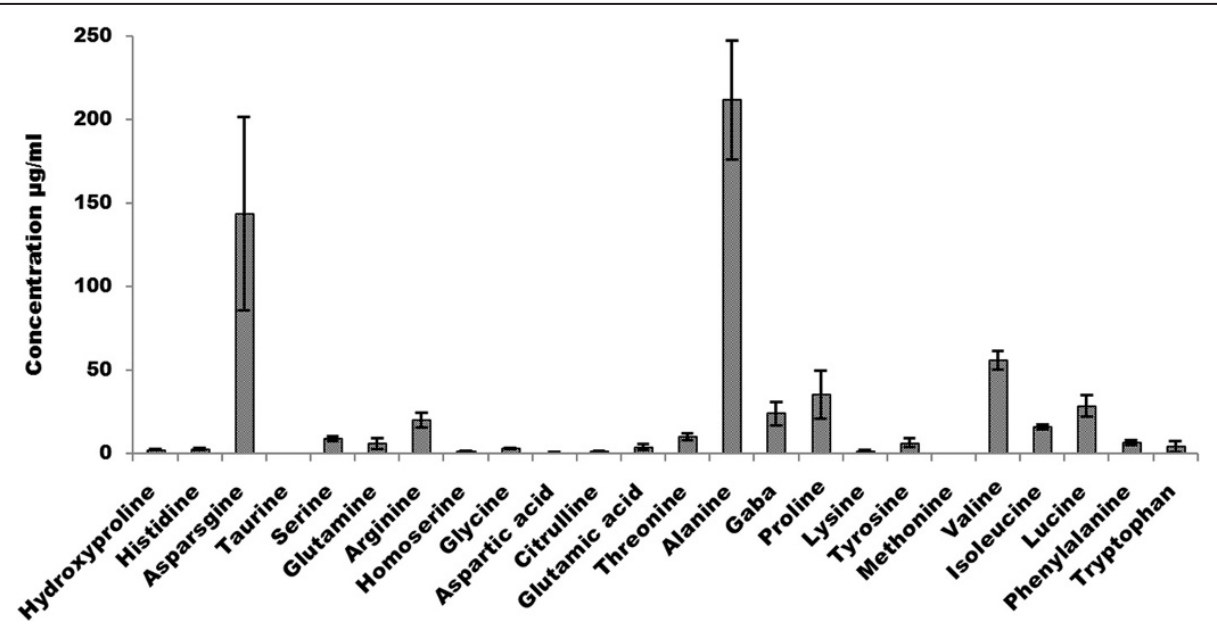

Figure 4 Mass spectroscopic estimation of TCW. Estimation of amino acid and metabolites for six different TCW samples was done through LC-MS/SRM method. The median for each compound in these samples was calculated. Variation of amino acids concentration among six different samples of TCW has been indicated as error bar. 


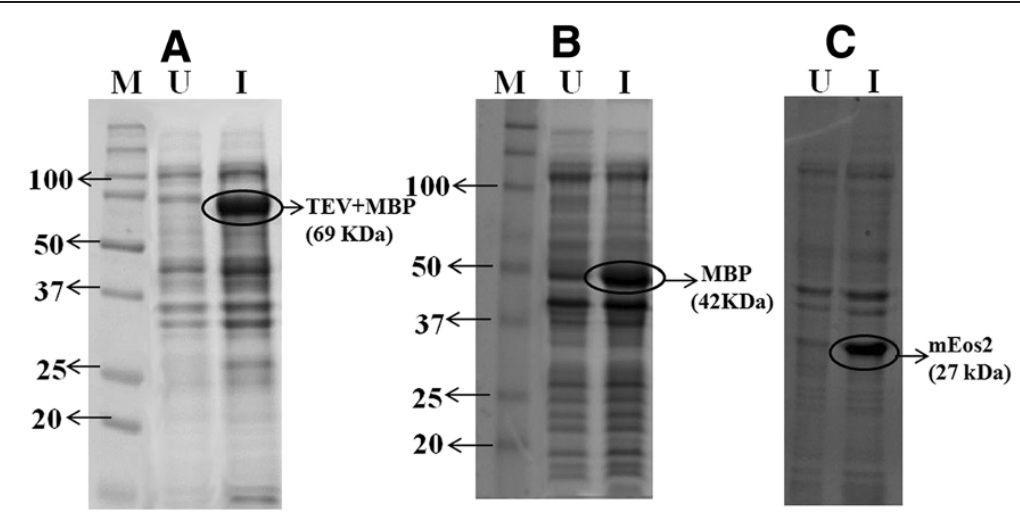

Figure 5 Recombinant protein expression in E.coli grown in TCW media. Protein expression was analysed in 12\% SDS-PAGE. (A) MBP-TEV protease expression at $69 \mathrm{KDa}$ harvested after 5 hours (B) MBP expressed at $42 \mathrm{KDa}$ harvested after 5 hours (C) mEos2 expressed at $27 \mathrm{KDa}$ harvested after overnight induction. All samples normalised based on their $\mathrm{OD}_{600}$. Lane M: Marker, Lane U: Uninduced, Lane I: Induced. MBP \& MBP-TEV constructs were induced with 0.4 mM IPTG while mEos2 with 0.1 mM IPTG.

can be used as a potential media for the expression of recombinant proteins.

To demonstrate the protein expression in E.coli using TCW, three different recombinant proteins were chosen. MBP (42 KDa) is a complex regulatory and transport system used in fusion to the protein of interest to increase the solubility of recombinant proteins [25]. MBP is thus, an easily expressible target in E.coli. A longer $(69 \mathrm{KDa})$ construct, which was made from the fusion of MBP and TEV protease (a highly site-specific cysteine protease commonly used for removing affinity tags from purified proteins) was taken as a second construct. The third protein of interest mEoS2 $(27 \mathrm{KDa})$ is a fluorescent protein, which gives a visually detectable green colour ensuring the proteins produced were in the native fold and functional. The constructs were induced using appropriate concentration of IPTG (see Methods), where MBP and MBP- TEV protease was controlled by tac promoter (Ptac) and mEoS2 was controlled by T7 promoter. Successful expression of the above proteins was confirmed by $12 \%$ SDS-PAGE (Figure 5). As discussed earlier, biomass of $E$. coli is not consistent in different TCW, which is proportionately related to protein expression. Hence, protein expression was carried out using TCW-S (supplemented with $\left.25 \mathrm{mM}\left(\mathrm{NH}_{4}\right)_{2} \mathrm{SO}_{4}\right)$. As compared to LB, expression level of mEoS2 was high in TCW-S with less leaky expression. While for MBP, no leaky expression was observed and the expression level was almost equivalent to LB (Figure 6).

Recombinant protein expression in P.pastoris is regulated by AOX1 promoter (most widely used), which is induced by methanol; hence the expression media should be devoid of all other carbon sources [26]. TCW contains sugars like glucose, fructose, sucrose etc., which would handicap protein expression. Generally, YPD media is used to generate biomass and is transferred into

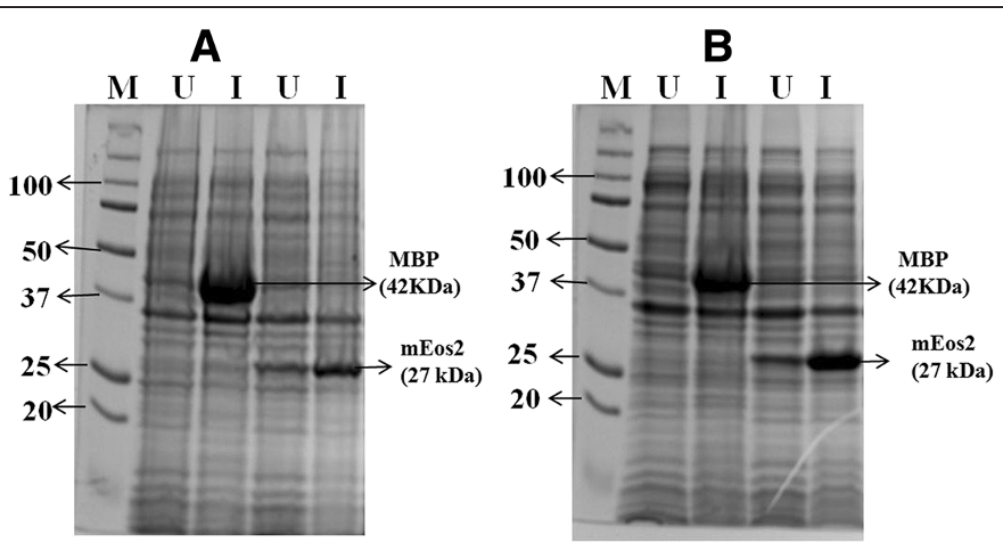

Figure 6 Recombinant Protein expression in E.coli grown in TCW-S. Protein expression in TCW supplemented with $\left(\mathrm{NH}_{4}\right)_{2} \mathrm{SO}_{4}$ and its comparison to the expression in LB media. (A) MBP (42 KDa) and mEos2 (27 KDa) expression in LB media (B) MBP and mEos2 expression in TCW supplemented with $\left(\mathrm{NH}_{4}\right)_{2} \mathrm{SO}_{4}$. Lane M: Marker, Lane U: Uninduced, Lane I: Induced. 
buffered minimal methanol medium (Invitrogen, USA) for inducing the AOX1 promoter to express the protein of interest. Alternatively, TCW can be used to generate biomass in place of YPD media. If proper optimization for complete utilization of the above mentioned carbon sources is achieved then TCW would be a potential media for protein expression in P.pastoris as well.

\section{Conclusion}

Successful expression of MBP, MBP-TEV and mEos2 was observed in TCW and TCW-S, which was comparable that of expression in LB. However, difference in growth rate of E.coli and P.pastoris was observed, as there was inconsistency of nitrogen source in TCW, which was normalized by the supplementation of TCW with $25 \mathrm{mM}$ $\left(\mathrm{NH}_{4}\right)_{2} \mathrm{SO}_{4}$. Therefore, the use of TCW alone is not advisable. In order to obtain consistency of growth, $25 \mathrm{mM}$ $\left(\mathrm{NH}_{4}\right)_{2} \mathrm{SO}_{4}$ supplementation is recommended. In future, other nitrogen sources can be supplemented to obtain higher saturation density in E.coli as well as other microbes. Thus, we conclude that TCW can be employed as a natural, inexpensive and efficient growth media for expression of recombinant proteins.

\section{Competing interests}

The authors are co-inventors on a patent application related to the work described in this study, which has been filed through Center for Cellular and Molecular platforms (C-CAMP), Bangalore. The study was financially supported by C-CAMP.

\section{Authors' contribution}

MN conceptualised and designed the experiments and the study was coordinated by MN, NS and SKV. NS and SKV performed the experiments and were involved in data acquisition. NS, SKV and MN were involved in drafting of manuscript, analysis and interpretation of data. All the authors read and approved the final manuscript.

\section{Acknowledgments}

We express our sincere thanks to Prof. Ramaswamy.S, The CEO of Centre for Cellular and Molecular Platforms (C-CAMP), NCBS-TIFR, Bangaluru, India. Special gratitude to Dr.Kannan Rangiah, Technology Manager of Metabolomics Facility, (C-CAMP) for his immense help in mass spectroscopic estimation and data analysis and Bangalore test house, (Bangaluru, India) for their help in estimation of total carbohydrates and total nitrogen in TCW. We would also like to thank Dr.Taslimarif Saiyed, COO, C-CAMP for his support. We extend our thanks to Mr. Sumukh Mysore of PTC, C-CAMP for his constructive criticism and insightful advice during the study.

Received: 11 March 2013 Accepted: 19 August 2013

Published: 2 September 2013

\section{Reference}

1. Broadhurst J: The effect of meat and meat extract media upon the fermentative activity of Streptococcci. Journal Infect Dis 1913, 13:404-440.

2. Atlas RM: Handbook of microbiological media for the examination of food Kentucky. USA: CRC prss; 2006.

3. Vigliar R, Sdepanian VL, Fagundes Neto U: Biochemical profile of coconut water from coconut palms planted in an inland region. J Pediatr (Rio J) 2006, 82:308-312.

4. Mauney JR, Hillman WS, Miller CO, Skoog F, Clayton RA, Strong FM: Bioassay, purification and properties of a growth factor from coconut. Physiol Plant 1952, 5:485-497.
5. Renato G, GraßI W, Rau U: Coconut water as a novel culture medium for the biotechnological production of Schizophyllan. J Nature Stud 2009, 7(2). January-June.

6. Lin MT, Dianese JC: A coconut-agar medium for rapid detection of aflotoxin production by aspergillus spp. Am Phytophathological Soc 1976, 66:1466-1469.

7. Oloke JK, Glick BR: Expression of melanin and insecticidal protein from Rhodotorula glutinis in Escherichia coli. Afr J Biotechnol 2006, 5:327-332.

8. Unagul P, Santachai C, Phadungruengluij S, Manopsuphantharika M, Tanticharoen M, Verduyn C: Coconut water as a medium additive for the production of docosahexaenoic acid (C22:6 n3) Schizochytriummangrovei Sk-02. Bioresour Technol 2007, 98:281-287.

9. Kuntiya A, Hanmoungjai P, Techapun C, Sasaki K, Seesuriyachan P: Influence of $\mathrm{pH}$, sucrose concentration and agitation speed on exopolysaccharide production by Lactobacillus confusus using coconut water as a raw material substitute. Int I Sci Technol 2010, 4:318-330.

10. Prabakaran G, Hoti SL, Manonmani AM, Balaraman K: Coconut water as a cheap source for the production of $\delta$ endotoxin of Bacillus thuringiensis var. israelensis, a mosquito control agent. Acta Trop 2008, 105:35-38.

11. Boughton BA, Callahan DL, Silva C, Bowne J, Nahid A, Rupasinghe T, Tull DL, McConville MJ, Bacic A, Roessner U: Comprehensive profiling and quantitation of amine group containing metabolites. Anal Chem 2011, 83:7523-7530.

12. Michel D, Gilles KA, Hamilton JK, Rebers PA, Fred S: Colorimetric method for determination of sugars and related substances. Anal Chem 1956, 28:350-356.

13. Guebel DV, Nudel BC, Giuliettietti AM: A simple and rapid micro-Kjeldahl method for total nitrogen analysis. Biotechnol Tech 1991, 5:427-430.

14. Presser KA, Ratkowsky DA, Ross T: Modelling the growth rate of Escherichia coli as a function of $\mathrm{pH}$ and lactic acid concentration. Appl Environ Microbiol 1997, 63:2355-2360.

15. Jackson JC, Gordon A, Wizzard G, Mccook K, Rolle R: Changes in chemical composition of coconut (Cocos nucifera $\mathrm{L}$.) water during maturation of the fruit. J Sci Food Agri 2004, 84:1049-1052.

16. Ogundiya MO: Glucose content of nut water in four varieties of coconut palm. (Cocos nucifera) J Sci Food Agric 1991, 56:399-402.

17. Pue AG, Rivu W, Sundarrao C, Singh K: Preliminary studies on changes in coconut water during maturation of the fruit. Sci New Guinea 1992, 18:81-84.

18. Santoso U, Kubo K, Ota T, Tadokoro T, Maekawa A: Nutrient composition of kopyor coconuts (Cocos nucifera L.). Food Chem 1995, 51:299-304.

19. Kuberski T, Roberts A, Linehan B, Bryden RN, Teburae M: Coconut water as a rehydration fluid. N Z Med J 1979, 90:98-100.

20. Thampan PK, Rethinam P: Coconut products for health and medicine. Indian Coconut J 2004, 35:6-15.

21. Neerathilingam $M$, Markley JL: Auto-induction medium containing glyphosate for high-level incorporation of unusual aromatic amino acids into proteins. Biotechniques 2010, 49(3):659-661.

22. Studier FW: Protein production by auto-induction in high-density shaking cultures. Protein Exp Purif 2005, 41:207-234.

23. Gombert AK, Kilikian BV: Recombinat gene expression in Escherichia coli cultivation using lactose as inducer. J Biotechnol 1998, 60:47-54.

24. Novy R, Morris B: Use of glucose to control basal expression in the $p E T$ System. In Novations 2001, 13:8-10.

25. Kapust RB, Waugh DS: Escherichia coli maltose-binding protein is uncommonly effective at promoting the solubility of polypeptides to which it is fused. Protein Sci 1999, 8:1668-1674.

26. Joan Lin C, Cregg JM: Heterologous protein expression in the methylotrophic yeast Pichia pastoris. FEMS Microbiol Rev 2000, 24:45-66.

doi:10.1186/1472-6750-13-70

Cite this article as: Sekar et al:: Tender coconut water an economical growth medium for the production of recombinant proteins in Escherichia coli. BMC Biotechnology 2013 13:70. 